\title{
Structural Changes of $\beta$-Casein Induced by Temperature and pH Analysed by Nuclear Magnetic Resonance, Fourier-Transform Infrared Spectroscopy, and Chemometrics
}

\author{
Tatijana Markoska $^{1}$ (D), Davor Daniloski ${ }^{1,2}$ (D), Todor Vasiljevic ${ }^{1}$ (D) and Thom Huppertz Th, $^{1,4, *(\mathbb{D})}$ \\ 1 Advanced Food Systems Research Unit, Institute for Sustainable Industries \& Liveable Cities, \\ College of Health and Biomedicine, Victoria University, Melbourne, VIC 8001, Australia; \\ tatijana.markoska@live.vu.edu.au (T.M.); davor.daniloski@live.vu.edu.au (D.D.); \\ todor.vasiljevic@vu.edu.au (T.V.) \\ 2 Teagasc Food Research Centre, Food Chemistry and Technology Department, Moorepark, Fermoy, \\ P61 C996 Cork, Ireland \\ 3 FrieslandCampina, 3818 LE Amersfoort, The Netherlands \\ 4 Food Quality and Design Group, Wageningen University \& Research, 6808 WG Wageningen, The Netherlands \\ * Correspondence: thom.huppertz@wur.nl
}

check for updates

Citation: Markoska, T.; Daniloski, D. Vasiljevic, T.; Huppertz, T. Structural Changes of $\beta$-Casein Induced by Temperature and $\mathrm{pH}$ Analysed by Nuclear Magnetic Resonance, Fourier-Transform Infrared Spectroscopy, and Chemometrics. Molecules 2021, 26, 7650. https:// doi.org/10.3390/molecules 26247650

Academic Editor: Mirella Nardini

Received: 4 December 2021

Accepted: 15 December 2021

Published: 17 December 2021

Publisher's Note: MDPI stays neutral with regard to jurisdictional claims in published maps and institutional affiliations.

Copyright: (c) 2021 by the authors. Licensee MDPI, Basel, Switzerland. This article is an open access article distributed under the terms and conditions of the Creative Commons Attribution (CC BY) license (https:// creativecommons.org/licenses/by/ $4.0 /)$.
Abstract: This study investigated structural changes in $\beta$-casein as a function of temperature (4 and $20^{\circ} \mathrm{C}$ ) and $\mathrm{pH}(5.9$ and 7.0). For this purpose, nuclear magnetic resonance (NMR) and Fourier-transform infrared (FTIR) spectroscopy were used, in conjunction with chemometric analysis. Both temperature and $\mathrm{pH}$ had strongly affected the secondary structure of $\beta$-casein, with most affected regions involving random coils and $\alpha$-helical structures. The $\alpha$-helical structures showed great $\mathrm{pH}$ sensitivity by decreasing at $20{ }^{\circ} \mathrm{C}$ and diminishing completely at $4{ }^{\circ} \mathrm{C}$ when $\mathrm{pH}$ was increased from 5.9 to 7.0. The decrease in $\alpha$-helix was likely related to the greater presence of random coils at $\mathrm{pH} 7.0$, which was not observed at $\mathrm{pH} 5.9$ at either temperature. The changes in secondary structure components were linked to decreased hydrophobic interactions at lower temperature and increasing $\mathrm{pH}$. The most prominent change of the $\alpha$-helix took place when the $\mathrm{pH}$ was adjusted to 7.0 and the temperature set at $4{ }^{\circ} \mathrm{C}$, which confirms the disruption of the hydrogen bonds and weakening of hydrophobic interactions in the system. The findings can assist in establishing the structural behaviour of the $\beta$-casein under conditions that apply as important for solubility and production of $\beta$-casein.

Keywords: FTIR; NMR; $\beta$-casein; secondary structure; temperature; $\mathrm{pH}$

\section{Introduction}

Caseins represent the major protein constituents of the bovine milk (80\%), comprised of four major phosphoproteins, $\alpha_{\mathrm{S}^{-}}, \alpha_{\mathrm{S} 2^{-}}, \beta-$, and $\mathrm{k}$-casein at concentration of $12-15,3-4$, 9-11 and 2-4 g/L, respectively [1]. In the dairy industry, the structural organisation of caseins can have a great effect on the functional properties of milk and the quality of the final product due to various interactions (hydrophobic, electrostatic, van der Waals forces, or covalent bonds) yielding to different properties. As the most amphiphilic, bovine $\beta$-casein represents $35 \%$ of the caseins in the bovine milk with 209 amino acids in the polypeptide chain and average molecular weight of $24 \mathrm{kDa}$ [2]. Due to the presence of many relatively hydrophobic parts in the $\beta$-casein molecule with great number of Pro residues, the molecule can adopt flexible conformations. These conformations are characterised by large range of inter or intra molecular interactions, fewer secondary and tertiary structures, while containing more random coil organisations [3].

There have been multiple studies analysing the secondary structure of $\beta$-casein. The summarised findings included the presence of $7-25 \% \alpha$-helical structures, $15-33 \% \beta$-sheets, 
$20-30 \%$ turns, and $20-25 \%$ polyproline II structures [2,4-6]. The predicted $\alpha$-helical structures are likely in the $\mathrm{N}$-terminal part of the $\beta$-casein, $\mathrm{f}(1-40)$, due to the presence of phosphoserine residues that carry the net charge of the molecule [7]. The apolar residues present in the C-terminal part of $\beta$-casein, $\mathrm{f}(136-209)$, are responsible for the appearance of $\beta$-sheet structures due to higher hydrophobicity in this region $[7,8]$.

Temperature is an important factor in regards to the $\beta$-casein release from the casein micelle. In a cold environment, due to weakening of hydrophobic attraction, selective solubilisation of $\beta$-casein takes place, leading to increased solubility of $\beta$-casein during cold storage [9]. At low temperature, $\beta$-casein appears as monomer with structural transitions due to cold denaturation. The dissociation of $\beta$-casein from the casein micelle was previously observed to be the greatest at $\mathrm{pH} 5$ and a temperature below $4{ }^{\circ} \mathrm{C}$ [10]. Moreover, the net negative charge at high $\mathrm{pH}$ increases as a result of deprotonation of carboxyl groups and loss of the positive charge of amino acids including His. The increase in electrostatic repulsion takes place as a result of the negative charge of the phosphoseryl residues [11]. The transition that takes place on the $\beta$-casein molecule based on $\mathrm{pH}$ and temperature adjustment can have a significant effect on the secondary structure of the molecule. The impact of both $\mathrm{pH}$ and temperature on $\beta$-casein and overall milk protein structure play an important role in protein stability during processing of milk and milk products and their storage. The $\mathrm{pH}$ of dairy products may vary from $<4$ for some fermented dairy to $>7$ for some dairy ingredients and infant formula products, whereas storage occurs both at $\sim 4{ }^{\circ} \mathrm{C}$ for pasteurised products and at room temperature for sterilised products.

Even though several studies already confirmed the presence of some structural elements in the $\beta$-casein molecule, it would be valuable to know how this particular casein adapts its secondary structural elements in different environments $[4,12,13]$. Thus, the aim of the present research was to identify the structural components of $\beta$-casein using Fourier-transform infrared spectroscopy (FTIR) and nuclear magnetic resonance (NMR). FTIR spectroscopy provides information of the structural changes in proteins by absorption of the stretching/bending vibrations in different regions [14]. Consequently, NMR provides detailed information of the protons in the molecule, which evaluates the primary position of the atoms in the molecule [15]. Both methods are nondestructive with minimal sample preparation and can provide information under any condition. The current work involved structural analysis of $\beta$-casein at two $\mathrm{pH}$ values $(\mathrm{pH} 5.9$ and $\mathrm{pH} 7.0)$ and two temperatures $\left(4\right.$ and $20^{\circ} \mathrm{C}$ ) in order to establish the structural transitions of $\beta$-casein. The selected temperature was used to observe the structural transition of $\beta$-casein in most used storage conditions for milk proteins. The $\mathrm{pH} 7.0$ was used to observe how $\beta$-casein structure changes in $\mathrm{pH}$ environment close to native $\mathrm{pH}$ in milk and $\mathrm{pH} 5.9$ were used as the native $\mathrm{pH}$ of synthesised $\beta$-casein and also were important for curd stability during milk coagulation.

\section{Results and Discussion}

In the current study, FTIR and NMR were used to examine the structural changes in $\beta$-casein resulting from changes in $\mathrm{pH}$ and temperature. In the Amide I region of the FTIR spectra, six structural features were distinguished and analysed (Table 1).

From the peak area calculations of the second derivative spectra, the most significant differences $(p \leq 0.05)$ as a result of changes in $\mathrm{pH}$ and temperature were observed in random coil, $\alpha$-helix, and $\beta$-turn structures. At $\mathrm{pH} 7.0$, the percentage of random coil structure was $\sim 15 \%$ higher at $4{ }^{\circ} \mathrm{C}$ than at $20{ }^{\circ} \mathrm{C}$, whereas random coil structures were not detected at pH 5.9 at either temperature. The assigned random coil structures have previously been shown to include short polyproline II (PPII) helix/chains [16]. Bovine $\beta$-casein contains 35 Pro residues, evenly distributed along the 209 amino acid polypeptide chain, which favours the formation of PPII structures [4]. The lack of detected random coil structures at $\mathrm{pH} 5.9$ indicates that there was no substantial unfolding of the secondary structure of the protein at this $\mathrm{pH}$ [17]. The absence of random coils in $\beta$-casein at $\mathrm{pH} 5.9$ appeared to correlate with a greater amount of $\alpha$-helical structures, at both 4 and $20^{\circ} \mathrm{C}$. At 
$20{ }^{\circ} \mathrm{C}$, the $\alpha$-helix content at $\mathrm{pH} 7.0$ was half of that observed at $\mathrm{pH} 5.9$, whereas $\alpha$-helical structures were not detected at $\mathrm{pH} 7.0$ at $4{ }^{\circ} \mathrm{C}$. The $\beta$-turn structures were affected by temperature, but not by $\mathrm{pH}$; at both $\mathrm{pH} 5.9$ and 7.0, fewer $\beta$-turns were observed at 20 than at $4{ }^{\circ} \mathrm{C}$. Farrell et al. [4] stated that with the temperature increase the conversion from $\beta$-turns and $\beta$-sheet to PPII conformations might occur. Hence, in line with these previous findings in combination with the present data of random and turn conformations (Table 1), there is a reasonable possibility of transformation of these structures into PPII helices, whose content was found to be between 20 and $25 \%$ within the $\beta$-casein molecule $[5,6]$. The formation of $\beta$-turns in caseins is promoted by the Pro residues by cross-linking with neighbouring residues via van der Waals interactions acting as a $\beta$-turn inducer [8].

Table 1. Total percentage areas of different secondary structures in Amide I in $\beta$-CN in FTIR including side chain, $\beta$-sheet, random coil, $\alpha$-helix $\beta$-turn, and aggregated $\beta$-sheets. The selected band frequency for each structural component is presented in $\mathrm{cm}^{-1}$. The peak area percentage is presented for temperature of 4 and $20^{\circ} \mathrm{C}$ and $\mathrm{pH}$ of 5.9 and 7.0 .

\begin{tabular}{|c|c|c|c|c|c|}
\hline \multirow{3}{*}{ Band Assessment } & \multirow{3}{*}{$\begin{array}{l}\text { Band Frequency } \\
\left(\mathrm{cm}^{-1}\right)\end{array}$} & \multicolumn{4}{|c|}{ Peak Area (\%) } \\
\hline & & \multicolumn{2}{|c|}{ Temperature $4^{\circ} \mathrm{C}$} & \multicolumn{2}{|c|}{ Temperature $20^{\circ} \mathrm{C}$} \\
\hline & & pH 5.9 & pH 7.0 & pH 5.9 & pH 7.0 \\
\hline Side chain & $1608-1610$ & $3.99 \pm 0.53^{a}$ & $5.40 \pm 0.09^{\mathrm{a}}$ & $3.92 \pm 0.34^{\mathrm{a}}$ & $4.33 \pm 0.60^{a}$ \\
\hline$\beta$-sheet & $1620-1630$ & $26.04 \pm 3.55^{\mathrm{a}}$ & $23.07 \pm 4.24^{\mathrm{a}}$ & $26.70 \pm 4.03^{\mathrm{a}}$ & $23.72 \pm 2.47^{a}$ \\
\hline Random coil & $1640-1645$ & $\mathrm{n} / \mathrm{d}$ & $46.53 \pm 5.81^{b}$ & $\mathrm{n} / \mathrm{d}$ & $31.07 \pm 8.71^{\mathrm{a}}$ \\
\hline$\alpha$-helix & $1646-1652$ & $42.98 \pm 3.41^{b}$ & $\mathrm{n} / \mathrm{d}$ & $45.24 \pm 3.76^{b}$ & $21.77 \pm 2.59^{a}$ \\
\hline$\beta$-turn & $1677-1679$ & $22.25 \pm 1.87^{c}$ & $20.04 \pm 1.35^{b c}$ & $17.00 \pm 2.29 \mathrm{ab}$ & $13.34 \pm 4.66^{\mathrm{a}}$ \\
\hline $\begin{array}{c}\text { Aggregated } \\
\beta \text {-sheet }\end{array}$ & $1689-1690$ & $4.75 \pm 1.61^{\mathrm{a}}$ & $4.96 \pm 0.97^{\mathrm{a}}$ & $7.15 \pm 1.36^{a}$ & $5.78 \pm 2.02^{a}$ \\
\hline
\end{tabular}

$\mathrm{a}, \mathrm{b}, \mathrm{c}$ Mean values within a row that do not share a common superscript letter are significantly different $(p \leq 0.05) ; \mathrm{n} / \mathrm{d}=$ not detected.

The observed differences in the peak area (Table 1) were further confirmed by PCA results (Figure 1).
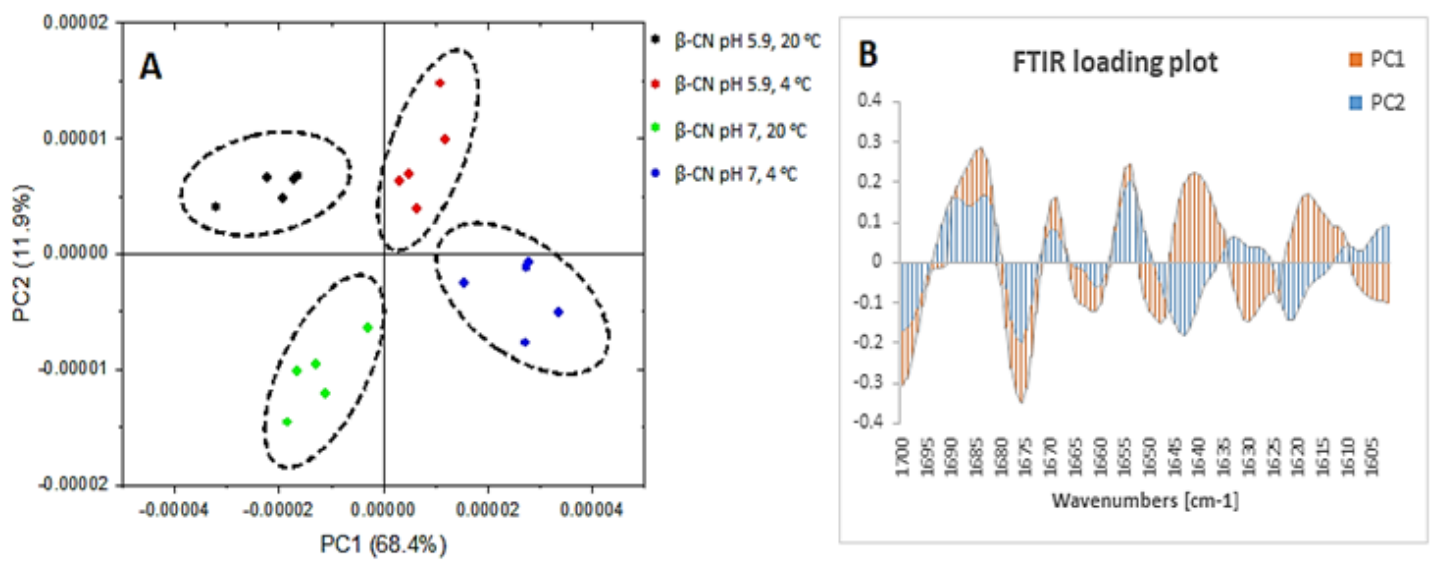

Figure 1. Principal components score plot (A) and loading plot (B) of $\beta$-casein of the FTIR spectra in region $1700-1600 \mathrm{~cm}^{-1}$ where $\beta$-casein at $\mathrm{pH} 5.9$ and temperature of $20^{\circ} \mathrm{C}$ (black), $\beta$-casein at $\mathrm{pH} 5.9$ and temperature of $4{ }^{\circ} \mathrm{C}$ (red), $\beta$-casein at pH 7.0 and temperature of $20^{\circ} \mathrm{C}$ (green) and $\beta$-casein at pH 7.0 and temperature of $4{ }^{\circ} \mathrm{C}$ (blue) are in (A) and PC1 (orange) and PC2 (blue) are in (B).

In addition, PC1 confirmed $68.4 \%$ difference between the samples at 4 and $20{ }^{\circ} \mathrm{C}$, while PC2 confirmed 11.9\% difference between samples at pH 5.9 and pH 7.0 (Figure 1A). The loading score in Figure 1A visually separated the groupings of samples that differed in temperature along the PC1. The PC1 also distinguished the differences in the structural components between these samples, which are confirmed in the loading plot in Figure 1B. 
The PC1 identified high loading for a peak at $1650 \mathrm{~cm}^{-1}$ ( $\alpha$-helix) for samples at $20{ }^{\circ} \mathrm{C}$, confirming a greater presence of this secondary structure at this temperature. On the other hand, the observed high loading for peak at $1640 \mathrm{~cm}^{-1}$ for samples at $4{ }^{\circ} \mathrm{C}$ confirmed the high level of random structures. PC1 also depicted slight changes in $\beta$-sheets by greater presence of intramolecular $\beta$-sheets $\left(1630 \mathrm{~cm}^{-1}\right)$ for samples at $20{ }^{\circ} \mathrm{C}$ and greater intermolecular $\beta$-sheets $\left(1620 \mathrm{~cm}^{-1}\right)$ for samples at $4{ }^{\circ} \mathrm{C}$. Similarly, PC2 differentiated the structural features occurring between samples with different $\mathrm{pH}$ values which were also present with different loadings in the loading plot in Figure 1B. In the PC2 loading plot (Figure 1B), great loadings were observed for a peak at $1653 \mathrm{~cm}^{-1}$ ( $\alpha$-helix) for samples at $\mathrm{pH} 5.9$ and at $1643 \mathrm{~cm}^{-1}$ (random coils) for samples at $\mathrm{pH}$ 7.0. Regarding the $\beta$-sheet structures, greater loading for a peak at $1630 \mathrm{~cm}^{-1}$ (intramolecular $\beta$-sheets) was observed for samples at $\mathrm{pH} 5.9$ and at $\mathrm{pH} 7.0$ greater loading shifted to indicate intermolecular $\beta$-sheets (peak $1623 \mathrm{~cm}^{-1}$ ). Thus, PC1 and PC2 successfully confirmed the previously observed changes for $\alpha$-helix and random structures and additionally confirmed differences in inter- and intramolecular $\beta$-sheets.

The ${ }^{1} \mathrm{H}-\mathrm{NMR}$ chemical shifts in proteins are sensitive to local structural rearrangements. Moreover, the conformational differences can be a result of multiple contributions including torsion angles coming from backbone and side chains, hydrogen bonding, electric fields, rings vibrations, and steric repulsions [18]. In the current work, we observed the variations in chemical shift distribution in four regions including methyl $-\mathrm{CH}_{3}-(0-1.5 \mathrm{ppm})$, aliphatic $-\mathrm{CH}_{2}-(1.5-3.5 \mathrm{ppm}), \mathrm{H}^{\alpha}$ amide region (3.5-5 ppm), and aromatic $/ \mathrm{H}^{\mathrm{N}}$-amino region (5.5-10 ppm). From the overlayed spectra in Figure 2A, a downfield shift of the proton chemical shifts can be seen at $4{ }^{\circ} \mathrm{C}$ compared to at $20^{\circ} \mathrm{C}$. In addition, the deshielding was observed in all the regions, except in the amino or backbone region (Figure 2A). Thus, in the amino region the peaks appeared in a broad pattern which overlayed in identical chemical shift positions (Figure 2A).
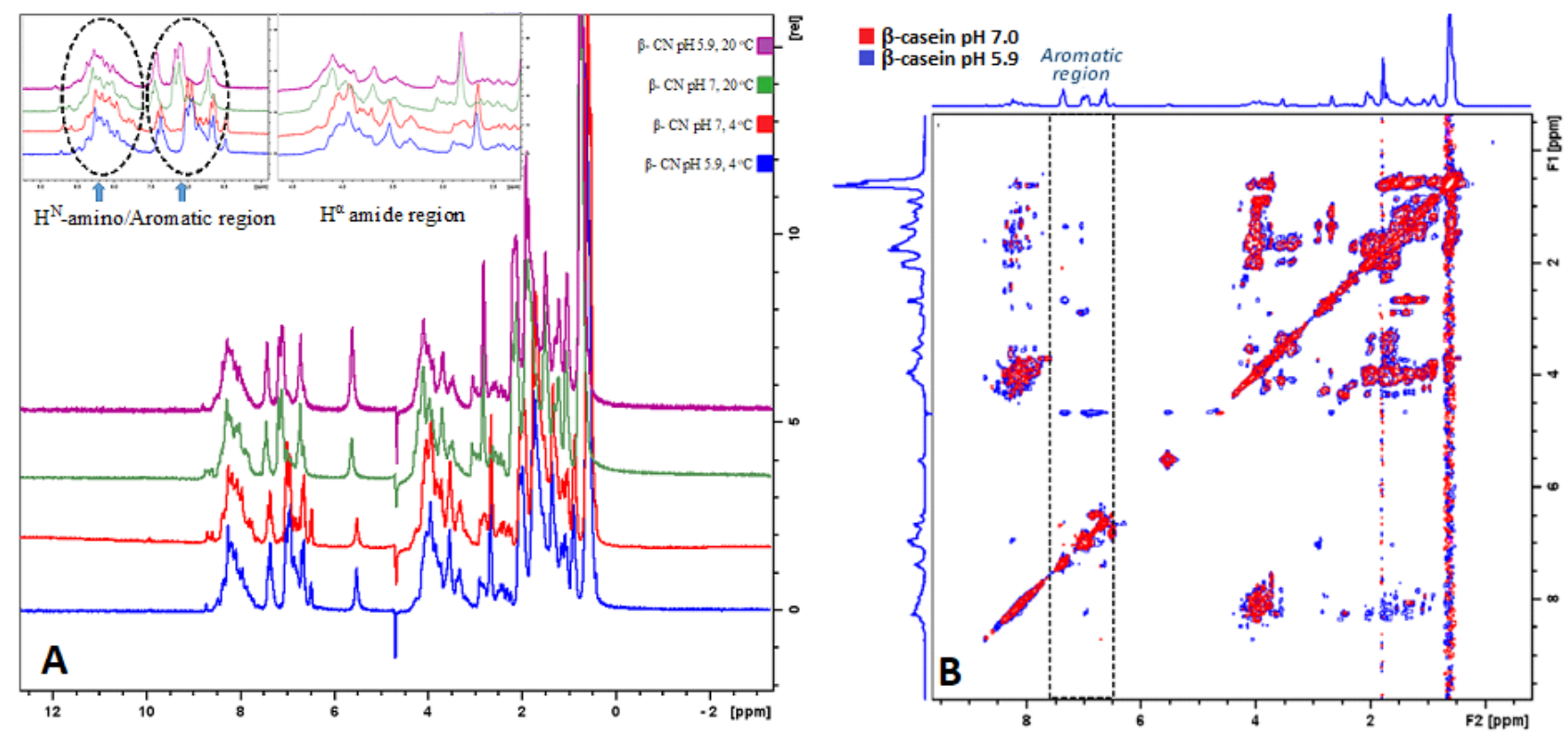

Figure 2. (A) Overlayed ${ }^{1} \mathrm{H}$ NMR spectra of $\beta$-casein at $\mathrm{pH} 5.9$ and temperature of $20^{\circ} \mathrm{C}$ (purple), $\beta$-casein at $\mathrm{pH} 5.9$ and temperature of $4{ }^{\circ} \mathrm{C}$ (blue), $\beta$-casein at $\mathrm{pH} 7.0$ and temperature of $20^{\circ} \mathrm{C}$ (green) and $\beta$-casein at $\mathrm{pH} 7.0$ and temperature of $4{ }^{\circ} \mathrm{C}$ (red). (B) Overlayed TOCSY NMR spectra of $\beta$-casein at $\mathrm{pH} 7.0$ (red) and $\beta$-casein at pH 5.9 (blue).

The deshielding in the other regions resulted by lowering of temperature to $4{ }^{\circ} \mathrm{C}$ was observed to be $0.2-0.3 \mathrm{ppm}$. The sensitivity of the ${ }^{1} \mathrm{H}$ chemical shift can be promoted by multiple factors, including the protein sensitivity to conformations, hydrogen bonding, ring vibrations, or electric fields [19]. In addition, the upfield and downfield shielding of the ${ }^{1} \mathrm{H}$ chemical shift can result from changes in the different components in the secondary 
structure $[18,20]$. In this study, an opposite effect by $0.3 \mathrm{ppm}$ downfield shift for the amide region was observed, which can relate to a lower presence of $\alpha$-helical structures at low temperature. In addition, from the integrated amide region we observed a significant decrease $(\leq 0.05)$ in the peak intensities by $\sim 3 \%$ at $4{ }^{\circ} \mathrm{C}$ compared to at $20{ }^{\circ} \mathrm{C}$ (Table 2$)$. This further confirms previously discussed FTIR results (Figure 1 and Table 1 ) regarding the absence or decline in $\alpha$-helical structures at low temperature.

Table 2. Total percentage areas peaks in different regions for $\beta$-casein in NMR including methyl, aliphatic, amide and amino region. The difference in the percentage is presented for $\beta$-casein at temperature of 4 and $20^{\circ} \mathrm{C}$ and $\mathrm{pH}$ of 5.9 and 7.0.

\begin{tabular}{|c|c|c|c|c|}
\hline \multirow{2}{*}{$\begin{array}{c}\text { Temperature } \\
\mathrm{pH}\end{array}$} & \multicolumn{2}{|c|}{$4^{\circ} \mathrm{C}$} & \multicolumn{2}{|c|}{$20^{\circ} \mathrm{C}$} \\
\hline & 5.9 & 7.0 & 5.9 & 7.0 \\
\hline Region/Integral & \multicolumn{4}{|c|}{$\beta$-Casein } \\
\hline Methyl & $19.48 \pm 0.16^{\mathrm{a}}$ & $17.63 \pm 0.27^{b}$ & $16.78 \pm 0.13^{b c}$ & $16.22 \pm 0.17^{c}$ \\
\hline Aliphatic & $16.22 \pm 0.16^{\mathrm{ab}}$ & $17.73 \pm 0.75^{\mathrm{a}}$ & $14.91 \pm 1.64^{b}$ & $13.90 \pm 0.35^{b c}$ \\
\hline Amide & $42.29 \pm 0.04^{b}$ & $42.82 \pm 0.21^{b}$ & $46.69 \pm 0.14^{a}$ & $46.32 \pm 0.17^{a}$ \\
\hline Amino & $22.01 \pm 0.34^{b}$ & $21.83 \pm 0.82^{b}$ & $22.62 \pm 0.41^{\mathrm{ab}}$ & $23.47 \pm 0.89^{a}$ \\
\hline
\end{tabular}

From the other regions of the NMR spectrum a greater amount of methyl groups at low temperature was observed, which was more present at pH 5.9 (Figure 2A). The peak observed in this region $(0-0.8 \mathrm{ppm})$ likely appeared from the side chains $\left(\mathrm{CH}_{3}\right)$ groups from Ile, Val, and Leu in $\beta$-casein [21]. The lower peak intensity for methyl groups at room temperature can be due losses of signal from the methyl side chains of Ile, Val, and Leu. An increase in $\mathrm{pH}$ from 5.9 to 7.0 led to slightly lower peaks for the methyl side chains (Table 2). The amide region of the $\beta$-casein presented slightly greater intensity at $20^{\circ} \mathrm{C}$ compared to that at $4{ }^{\circ} \mathrm{C}$ at both $\mathrm{pH}$ values (Table 2).

The change in $\mathrm{pH}$ from 5.9 to 7.0 lead to lower detection of the cross peaks in the aromatic region of the TOCSY spectra (Figure 2B). This spectral pattern was not affected by the temperature, i.e., at both 4 and $20{ }^{\circ} \mathrm{C}$ the TOCSY spectra of $\beta$-casein showed the same pattern in regard to the $\mathrm{pH}$. In the aromatic region of the TOCSY spectra the cross peaks present the interactions of the proton rings with the neighbouring protons of the amino acids [15]. It was previously suggested that charge-induced disruption of the cohesive interactions in the hydrophobic regions of the caseins occur as a result of $\mathrm{pH}$-induced charge modifications on side groups of amino acids, including Tyr, Lys, His, and Arg [22]. In the $\mathrm{pH}$ range currently studied, His would be the most susceptible to (de)protonation as a result of $\mathrm{pH}$ change. The side groups of these amino acids are detected in the aromatic region of the TOCSY spectra and the cross peaks in this region denote their connection with the neighbouring protons. It is known that increase in $\mathrm{pH}$ leads to greater intermolecular repulsion of caseins [11]. The addition of alkali to the $\beta$-casein solution can lead to disruption of existing hydrophobic connections, which was observed by reduction of the proton-proton cross association in the TOCSY spectra.

The observed structural differences resulted from changes in temperature and $\mathrm{pH}$ were also evaluated by PCA analysis (Figure 3). 

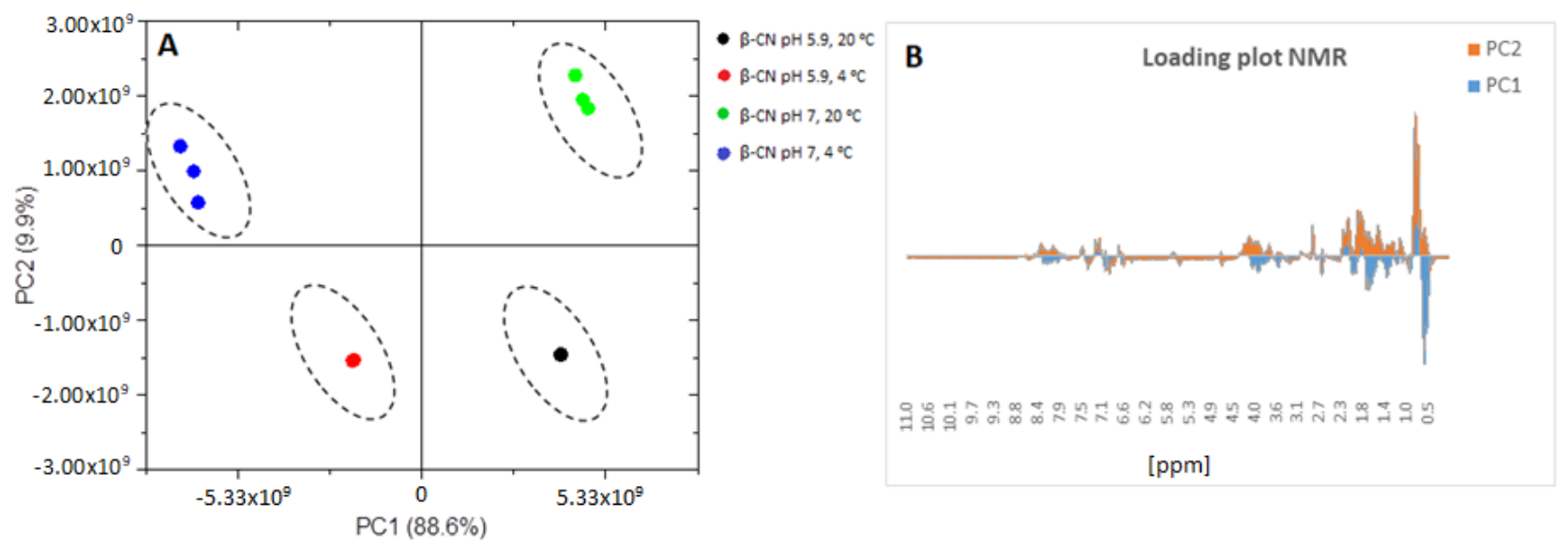

Figure 3. Principal components score plot (A) and loading plot (B) of $\beta$-casein of the NMR spectra in where $\beta$-casein at $\mathrm{pH} 5.9$ and temperature of $20^{\circ} \mathrm{C}$ (black), $\beta$-casein at $\mathrm{pH} 5.9$ and temperature of $4{ }^{\circ} \mathrm{C}$ (red), $\beta$-casein at $\mathrm{pH} 7.0$ and temperature of $20^{\circ} \mathrm{C}$ (green) and $\beta$-casein at $\mathrm{pH} 7.0$ and temperature of $4{ }^{\circ} \mathrm{C}$ (blue) are in (A) and PC1 (blue) and PC2 (orange) are in (B).

In the PCA loading score (Figure 3A), PC1 separated the results based on the temperature with $88.6 \%$ variance. On the other hand, $\mathrm{PC} 2$ separated the $\beta$-casein based on $\mathrm{pH}$ effect with $9.9 \%$ variance. PC1 has shown greater loading for a peak at $0.5 \mathrm{ppm}$ for samples at low temperature and $\mathrm{PC} 2$ indicated that this peak was mainly present for samples at $\mathrm{pH}$ 7.0. Moreover, PC2 showed that peak loadings in aliphatic (1.5-3.5 ppm) and amide regions (3.5-5.0 ppm) were more prominent for samples at $\mathrm{pH} 7.0$, whereas at $\mathrm{pH} 5.9$ greater loading was observed for the aromatic region (6.5-8.0 ppm). Furthermore, both PC1 and PC2 confirmed that in the aliphatic and aromatic regions the peak loading was more intense for samples at $\mathrm{pH} 7.0$ and temperature of $4{ }^{\circ} \mathrm{C}$, which can confirm the structural changes observed by FTIR occurring as a result of a cold environment and $\mathrm{pH}$.

\section{Material and Methods}

\subsection{Sample Preparation}

Bovine $\beta$-casein was purchased from Sigma-Aldrich (Sigma-Aldrich, St. Louis, MO, USA) with $>98 \%$ purity. The preparation process was performed by dispersion of $10 \mathrm{mg}$ $\beta$-casein in $1 \mathrm{~mL}$ of a mixture of $\mathrm{H}_{2} \mathrm{O}: \mathrm{D}_{2} \mathrm{O}(90 \%: 10 \%$, Sigma-Aldrich, St. Louis, MO, USA) for both FTIR and NMR analyses. The $\mathrm{pH}$ of $\beta$-casein in $\mathrm{H}_{2} \mathrm{O} / \mathrm{D}_{2} \mathrm{O}$ solution was measured using a $\mathrm{pH}$ meter (Metrohm AG, Herisau, Switzerland) equipped with a combined $\mathrm{pH}$ electrode with temperature sensor and fixed cable. The original $\mathrm{pH}$ of the protein solution was 5.9. The $\mathrm{pH}$ was further adjusted to 7.0 using $0.25 \mathrm{M} \mathrm{NaOH}$. The $\mathrm{pH}$ adjustment was carried out under continuous stirring of the solution and $\mathrm{pH}$ was additionally controlled before the structural measurements. Both $\beta$-casein solutions with $\mathrm{pH} 5.9$ and $\mathrm{pH} 7.0$ were analysed for structural features at 4 and $20^{\circ} \mathrm{C}$. The temperature for the FTIR analysis was monitored with temperature probe, however for the NMR analysis the temperature control was automated by the instrument.

\subsection{Fourier Transform Infrared Spectroscopy}

The secondary structure of $\beta$-casein as a function of $\mathrm{pH}$ and temperature was analysed using a FTIR spectrometer (Frontier, PerkinElmer, Boston, MA, USA) in the range of 4000 to $600 \mathrm{~cm}^{-1}$ with a resolution of $4 \mathrm{~cm}^{-1}$ and 16 scans for each spectrum. Before the start of the measurement for every sample, the background spectra were scanned using a blank diamond attenuated total reflectance (ATR) cell. At the start of the analysis the solvent spectrum $\left(90 \% \mathrm{H}_{2} \mathrm{O} / 10 \% \mathrm{D}_{2} \mathrm{O}\right)$ was recorded and used for subtraction from the sample spectra to eliminate the intense solvent signal. The spectra of five subsamples of each sample were taken by refilling the ATR cell. For the secondary structure analysis, the amide I region (1700-1600 $\mathrm{cm}^{-1}$ ) was analysed for $\mathrm{C}=\mathrm{O}$ stretching after 
applying Savitzky-Golay smoothing and 2nd derivative. The FTIR spectra and mean centering were analysed using Spectragryph software (version 1.2.7, Oberstdorf, Germany). The baseline of five repetitions for each sample was subtracted and the area of the peak was analysed by Origin software (Origin Pro 2021, v. 95E, OriginLab Corporation, Northampton, MA, USA). To estimate the area of each component representing secondary structures, a technique previously described elsewhere [23] was utilised. Briefly, each spectrum from five repetitions was treated by interpolation baseline mode and adjacent-averaging smoothing, then each peak in the 2nd derivative spectra was selected and integrated by high percentage. In the amide I region several peaks were analysed, including side chain $\left(1608-1610 \mathrm{~cm}^{-1}\right), \beta$-sheets $\left(1620-1630 \mathrm{~cm}^{-1}\right)$, random coil $\left(1640-1645 \mathrm{~cm}^{-1}\right), \alpha$-helix $\left(1646-1652 \mathrm{~cm}^{-1}\right), \beta$-turns $\left(1677-1679 \mathrm{~cm}^{-1}\right)$ and aggregated $\beta$-sheets $\left(1689-1690 \mathrm{~cm}^{-1}\right)$ [24].

\subsection{Nuclear Magnetic Resonance}

The NMR analysis was performed on a Bruker Avance spectrometer (Bruker BioSpin $\mathrm{GmbH}$, Rheinstetten, Germany) operating at a $600 \mathrm{MHz}$ transmitter frequency using $5 \mathrm{~mm}$ TXI probe with z- gradient. Proton NMR $\left({ }^{1} \mathrm{H}-\mathrm{NMR}\right)$ spectra were acquired using 16 scans and spectral width of $9615 \mathrm{~Hz}$ in three replications. The two-dimensional methods used in this study were total correlation spectroscopy (TOCSY) and nuclear Overhauser effect spectroscopy (NOESY). The 2D spectra were recorded using 8 scans and spectral width of $8196 \mathrm{~Hz}$ for TOCSY and $5882 \mathrm{~Hz}$ for NOESY spectra. The water suppression for spectra was performed using excitation sculpting with gradients with acquisition mode of States-TPPI (time-proportional phase incrementation). All spectral data were processed using TopSpin (version 4.0.6) software (Bruker BioSpin). The phase correction was performed manually by either 0th or 1st order correction for pk or the baseline and the noise correction was adjusted using qfil mode to $0.1 \mathrm{ppm}$ filter width and symmetrical noise correction for the homonuclear spectra. The NMR spectra were analysed using three NMR regions, i.e., amino/aromatic $\left(\mathrm{H}^{\mathrm{N}}\right)$, amide $\left(\mathrm{H}^{\alpha}\right)$, and aliphatic. From the aliphatic region, the methyl peak $\left(\mathrm{CH}_{3}\right)$ was analysed separately due to its high loading. All the peaks observed in these regions were manually integrated in TopSpin (version 4.0.6) software (Bruker BioSpin).

\subsection{Statistical Analysis and Spectral Data}

To assess the experimental results, Minitab version 20 software was used to analyse the data (Minitab Inc., State College, PA, USA). Hence, a two-way ANOVA and Tukey's test were performed with $\beta$-casein as fixed factor to evaluate if there was a difference between means $(p \leq 0.05)$. Unless otherwise specified, all measurements were taken in triplicate. In addition, principal component analysis (PCA) was used for both FTIR and NMR results to identify the changes in the secondary structure in $\beta$-casein samples based on the temperature and $\mathrm{pH}$ effect. PCA gives information by generating principal components (PCs) as a coordinated axis with a least possible loss of information. The groupings of the different samples were depicted in score plots and the loading plots were used for the wavenumbers responsible for peaks classification. The multivariate analysis was carried out at a $95 \%$ confidence level.

\section{Conclusions}

The combination of FTIR and NMR was very efficient in characterisation of structural differences in the $\beta$-casein molecule as affected by temperature and $\mathrm{pH}$. Moreover, both methods confirmed similar structural transitions of the $\beta$-casein molecule in regard to the applied conditions, indicating greater structural changes taking place as a result of the temperature. A temperature of $4{ }^{\circ} \mathrm{C}$ is critical for $\beta$-casein molecules due to lowering of hydrophobicity that results in unfolding and opening up of the native conformers and liberalisation of the monomers from the casein micelle. The restructuring of the $\beta$-casein was confirmed by FTIR results implying formation of more random coils at $4{ }^{\circ} \mathrm{C}$ at the expense of the $\alpha$-helical structure. Moreover, this was intensified by changing the $\mathrm{pH}$ 
to 7.0. Hence, the side chains of amino acids known as $\alpha$-helix inducers showed lower detection due to loss of hydrogen bonding resulting in reduction of the $\alpha$-helix in the $\beta$-casein polypeptide chain. The observed structural changes promoted by the temperature change were more intense at high $\mathrm{pH}$, however at $\mathrm{pH} 5.9$ the structural reorganisation was minor. The current findings confirmed that both $\mathrm{pH}$ and temperature have a great effect on structure of a $\beta$-casein molecule. Moreover, the results can assist in understanding the behavior of $\beta$-casein during $\beta$-casein production, solubility, processing of milk and milk products, and storage. In addition, FTIR and NMR have proven to successfully detect structural transition in $\beta$-casein. The combination of these methods can be further expanded to other proteins and assist in understanding protein behavior during food processing.

Author Contributions: T.M. conceived the study and research question; designed and wrote the original draft, conceptualised, reviewed, and edited the manuscript. D.D. gave critical feedback and analysis, and reviewed and edited the manuscript. T.H. and T.V. provided critical feedback and analysis, secured funding, reviewed and edited the manuscript, and supervised the study. All authors have read and agreed to the published version of the manuscript.

Funding: The first author is funded by a Victoria University Research Training Stipend Scholarship (Grant number-INT010).

Institutional Review Board Statement: Not applicable.

Informed Consent Statement: Not applicable.

Data Availability Statement: Data are contained within the article.

Conflicts of Interest: The authors declare that they have no known competing financial interest or personal relationships that could have appeared to influence the work reported in this paper.

Sample Availability: Samples of the compounds are not available from the authors.

\section{References}

1. Huppertz, T. Chemistry of the caseins. In Advanced Dairy Chemistry; Springer: Boston, MA, USA, 2013; pp. 135-160. [CrossRef]

2. Huppertz, T.; Fox, P.; Kelly, A. The caseins: Structure, stability, and functionality. In Proteins in Food Processing, 2nd ed.; Yada, R.Y., Ed.; Woodhead Publishing: Sawston, UK, 2018; pp. 49-92. [CrossRef]

3. Zhou, Z.; Zhu, M.; Zhang, G.; Hu, X.; Pan, J. Novel insights into the interaction mechanism of 5-hydroxymethyl-2-furaldehyde with $\beta$-casein and its effects on the structure and function of $\beta$-casein. LWT 2021, 152, 112360. [CrossRef]

4. Farrell, H.; Qi, P.; Wickham, E.; Unruh, J. Secondary structural studies of bovine caseins: Structure and temperature dependence of $\beta$-casein phosphopeptide (1-25) as analyzed by circular dichroism, FTIR spectroscopy, and analytical ultracentrifugation. J. Protein. Chem. 2002, 21, 307-321. [CrossRef]

5. Qi, P.X.; Wickham, E.D.; Farrell, H.M. Thermal and Alkaline Denaturation of Bovine $\beta$-Casein. Protein. J. 2004, $23,389-402$. [CrossRef] [PubMed]

6. Qi, P.X.; Wickham, E.D.; Piotrowski, E.G.; Fagerquist, C.K.; Farrell, H.M. Implication of C-terminal deletion on the structure and stability of bovine $\beta$-casein. Protein. J. 2005, 24, 431-444. [CrossRef] [PubMed]

7. Creamer, L.; Richardson, T.; Parry, D. Secondary structure of bovine $\alpha$ s1-and $\beta$-casein in solution. Arch. Biochem. Biophys. 1981, 211, 689-696. [CrossRef]

8. Kumosinski, T.; Brown, E.; Farrell, H., Jr. Three-dimensional molecular modeling of bovine caseins: An energy-minimized $\beta$-casein structure. J. Dairy Sci. 1993, 76, 931-945. [CrossRef]

9. Huppertz, T.; Hennebel, J.-B.; Considine, T.; Kelly, A.L.; Fox, P.F. A method for the large-scale isolation of $\beta$-casein. Food Chem. 2006, 99, 45-50. [CrossRef]

10. Post, A.; Arnold, B.; Weiss, J.; Hinrichs, J. Effect of temperature and pH on the solubility of caseins: Environmental influences on the dissociation of $\alpha$ S-and $\beta$-casein. J. Dairy Sci. 2012, 95, 1603-1616. [CrossRef]

11. Horne, D.S. Casein interactions: Casting light on the black boxes, the structure in dairy products. Int. Dairy J. 1998, 8, 171-177. [CrossRef]

12. Condict, L.; Kaur, J.; Hung, A.; Ashton, J.; Kasapis, S. Combined spectroscopic, molecular docking and quantum mechanics study of $\beta$-casein and ferulic acid interactions following UHT-like treatment. Food Hydrocoll. 2019, 89, 351-359. [CrossRef]

13. Farrell Jr, H.; Wickham, E.; Unruh, J.; Qi, P.; Hoagland, P. Secondary structural studies of bovine caseins: Temperature dependence of $\beta$-casein structure as analyzed by circular dichroism and FTIR spectroscopy and correlation with micellization. Food Hydrocoll. 2001, 15, 341-354. [CrossRef]

14. Gallagher, W. FTIR analysis of protein structure. Biochemistry 1997, 392, 662-666. 
15. Markoska, T.; Vasiljevic, T.; Huppertz, T. Unravelling Conformational Aspects of Milk Protein Structure-Contributions from Nuclear Magnetic Resonance Studies. Foods 2020, 9, 1128. [CrossRef] [PubMed]

16. Dukor, R.K.; Keiderling, T.A. Reassessment of the random coil conformation: Vibrational CD study of proline oligopeptides and related polypeptides. Biopolymers 1991, 31, 1747-1761. [CrossRef]

17. Nishinari, K.; Zhang, H.; Ikeda, S. Hydrocolloid gels of polysaccharides and proteins. Curr. Opin. Colloid. Interface. Sci. 2000, 5 , 195-201. [CrossRef]

18. Shen, Y.; Bax, A. Protein backbone chemical shifts predicted from searching a database for torsion angle and sequence homology. J. Biomol. NMR 2007, 38, 289-302. [CrossRef]

19. Mulder, F.A.; Filatov, M. NMR chemical shift data and ab initio shielding calculations: Emerging tools for protein structure determination. Chem. Soc. Rev. 2010, 39, 578-590. [CrossRef]

20. Wang, Y.; Jardetzky, O. Investigation of the neighboring residue effects on protein chemical shifts. J. Am. Chem. Soc. 2002, 124, 14075-14084. [CrossRef]

21. De Angelis Curtis, S.; Curini, R.; Delfini, M.; Brosio, E.; D’Ascenzo, F.; Bocca, B. Amino acid profile in the ripening of Grana Padano cheese: A NMR study. Food Chem. 2000, 71, 495-502. [CrossRef]

22. Vaia, B.; Smiddy, M.A.; Kelly, A.L.; Huppertz, T. Solvent-mediated disruption of bovine casein micelles at alkaline pH. J. Agric. Food. Chem. 2006, 54, 8288-8293. [CrossRef]

23. Daniloski, D.; McCarthy, N.A.; Markoska, T.; Auldist, M.J.; Vasiljevic, T. Conformational and physicochemical characteristics of bovine skim milk obtained from cows with different genetic variants of $\beta$-casein. Food Hydrocoll. 2022, 124, 107186. [CrossRef]

24. Markoska, T.; Huppertz, T.; Grewal, M.K.; Vasiljevic, T. FTIR analysis of physiochemical changes in raw skim milk upon concentration. LWT 2019, 102, 64-70. [CrossRef] 